\title{
PEMERHATI PILIHAN RAYA DOMESTIK DI MALAYSIA: KAJIAN KES AHLI AKADEMIK SEBAGAI PEMERHATI PILIHAN RAYA
}

\section{DOMESTIC ELECTION OBSERVERS IN MALAYSIA: A CASE STUDY OF ACADEMICS AS ELECTION OBSERVERS}

\section{Muhamad Takiyuddin Ismail dan Norazam Mohd Noor}

Political Science Programme, Faculty of Social Sciences and Humanities, Universiti Kebangsaan Malaysia, Selangor, MALAYSIA

Corresponding author: taki@ukm.edu.my

Published online: 30 April 2020

To cite this article: Muhamad Takiyuddin Ismail and Norazam Mohd Noor. 2020. Pemerhati pilihan raya domestik di Malaysia: Kajian kes ahli akademik sebagai pemerhati pilihan raya. Kajian Malaysia 38(1): 115-139. https://doi.org/10.21315/km2020.38.1.6

To link to this article: https://doi.org/10.21315/km2020.38.1.6

\section{ABSTRACT}

The result of the 14th General Election (GE14) on 9 May 2018 is a historic moment in the development of democracy in Malaysia. More than that, GE14 is also a testament that peaceful transition of power could occur in an electoral system that has always favoured the then government in power, the Barisan Nasional. One of the neglected areas in the academic discussion pertaining to Malaysian electoral process is the election monitoring. The Election Commission of Malaysia has introduced the concept of domestic election observers from GE12 to GE14. In contrast to the participation of non-governmental organisations (NGOs), GE14 witnessed the first involvement of three teams of observers from institutions of higher education. This number has increased to six after six series of by-elections that took place after GE14. This exploratory article assesses the potential and challenges in observing elections with a team comprised of academics. The finding suggests that compare to election monitoring groups such as Gabungan Pilihanraya Bersih dan Adil (BERSIH) 2.0, traditional NGOs or shadow observer groups that are politically affiliated and known for their partisan reputation, academics-based observation team is seen as more capable in terms of providing constructive and balanced inputs on election observation process. Nevertheless, the integrity of the academics-based observation team depends on the appointment of committed and non-partisan members, support given by its respective institutions of higher 
education and from the Election Commission of Malaysia. The establishment of a comprehensive academic observation team prior to GE15 is another prospect worthy to be explored, based on model implemented in Indonesia and Thailand.

Keywords: election monitoring, domestic election observers, academics-based election observers, Election Commission of Malaysia, Malaysia's 14th General Election

\begin{abstract}
ABSTRAK
Keputusan Pilihan Raya Umum ke-14 (PRU-14) yang berlangsung pada 9 Mei 2018 merupakan detik bersejarah dalam perkembangan demokrasi di Malaysia. Lebih dari itu, ia membuktikan peralihan kuasa boleh berlaku secara aman melalui sebuah sistem pilihan raya yang sentiasa memihak pada pemerintah ketika itu, Barisan Nasional. Salah satu bidang yang terabai daripada diperbahaskan dalam kajian akademik mengenai sistem pilihan raya di Malaysia ialah pemantauan dan pemerhatian pilihan raya. Suruhanjaya Pilihan Raya (SPR) Malaysia telah memperkenalkan konsep pemerhati pilihan raya domestik bermula daripada PRU-12 hinggalah PRU-14. Berbeza dengan penyertaan pasukan pemerhati daripada pertubuhan bukan kerajaan (NGO), PRU-14 menyaksikan penglibatan julung kali tiga pasukan pemerhati daripada institusi pengajian tinggi. Jumlah ini bertambah kepada enam selepas enam siri pilihan raya kecil yang berlangsung selepas PRU-14. Makalah eksplorasi ini menilai potensi dan cabaran dalam pengoperasian pasukan pemerhati daripada kumpulan ahli akademik. Kajian ini mencadangkan bahawa berbanding kumpulan pemantau pilihan raya seperti Gabungan Pilihanraya Bersih dan Adil (BERSIH) 2.0, NGO tradisional atau kumpulan pemerhati bayangan yang mempunyai affiliasi politik dan reputasi partisan, pasukan pemerhati daripada kumpulan ahli akademik dilihat lebih mampu memberi input yang konstruktif dan seimbang terhadap proses pemerhatian pilihan raya. Hal ini bagaimanapun turut dipengaruhi oleh pemilihan anggota pasukan pemerhati yang komited dan tidak partisan, sokongan yang diberikan oleh sesuatu institusi pengajian serta sokongan tambahan yang diberikan oleh SPR. Pewujudan sebuah pasukan pemerhati pilihan raya ahli akademik yang lebih menyeluruh sebelum PRU-15 turut merupakan prospek yang boleh diteroka berdasarkan model yang telah dilaksanakan di Indonesia dan Thailand.
\end{abstract}

Kata kunci: pemantauan pilihan raya, pemerhati pilihan raya domestik, pemerhati pilihan raya ahli akademik, Suruhanjaya Pilihan Raya Malaysia, Pilihan Raya Umum ke-14 


\section{PENGENALAN}

Pilihan Raya Umum ke-14 (PRU-14) yang berlangsung pada 9 Mei 2018 mencetuskan kejutan besar apabila rejim Barisan Nasional (BN) tumbang kepada Pakatan Harapan ( $\mathrm{PH})$ dalam apa yang dianggap sebagai "revolusi senyap" (Muhamad Takiyuddin dan Muhamad Nadzri 2018). Salah satu pertikaian yang muncul sebelum PRU-14 ialah kehadiran dan kredibiliti pasukan pemantauan pilihan raya yang dijemput oleh Suruhanjaya Pilihan Raya (SPR) Malaysia. Terlepas daripada pandangan umum ialah fakta bahawa PRU-14 turut menyaksikan penglibatan julung kalinya pasukan institusi pengajian tinggi di Malaysia sebagai pasukan pemerhati tempatan. Bermula daripada pengenalan pasukan pemerhati pilihan raya tempatan oleh SPR dalam PRU-14, pasukan pemerhati rasmi SPR didominasi sepenuhnya oleh pertubuhan bukan kerajaan (NGO). Namun, PRU14 menyaksikan penglibatan sulung pasukan pemerhati daripada tiga institusi pengajian tinggi awam iaitu Universiti Kebangsaan Malaysia (UKM), Universiti Teknologi MARA (UiTM) dan Universiti Kuala Lumpur (UniKL). Dalam enam siri pilihan raya kecil (PRK) yang diadakan selepas PRU-14, tiga lagi kumpulan akademik turut terlibat sebagai pemerhati pilihan raya iaitu Universiti Islam Antarabangsa Malaysia (UIAM), Universiti Malaya (UM) dan Institut Darul Ehsan (IDE).

Makalah eksplorasi ini mempunyai objektif yang sederhana iaitu memerihalkan secara umum disiplin bidang pemantauan pilihan raya di Malaysia dengan memfokuskan kepada pasukan pemerhati ahli akademik. Skop makalah ini tidak memfokuskan kepada pemerihalan terperinci atau analisis perbandingan mengenai peranan dan impak kesemua pemerhati pilihan raya tempatan bermula daripada PRU-12 sehinggalah selepas PRU-14 kerana ia pastinya menuntut ruang yang lebih luas. Begitu pun, bagi meletakkan konteks terhadap fokus makalah, beberapa perbandingan dan penyentuhan berhubung peranan pasukan pemerhati pilihan raya daripada kumpulan lain akan disisipkan.

Makalah ini mencadangkan bahawa berbanding kumpulan pemantau pilihan raya seperti Gabungan Pilihanraya Bersih dan Adil (BERSIH) 2.0, NGO tradisional atau kumpulan pemerhati bayangan yang mempunyai affiliasi dan reputasi partisan serta dilihat mewakili kepentingan tertentu, pasukan pemerhati daripada kumpulan ahli akademik dilihat lebih mampu memberi input yang konstruktif dan seimbang terhadap proses pemerhatian pilihan raya. Hal ini bagaimanapun turut dipengaruhi oleh pemilihan anggota pasukan pemerhati yang komited dan tidak partisan, kebebasan dan sokongan yang diberikan oleh sesuatu institusi pengajian serta sokongan yang diberikan oleh SPR. Pewujudan sebuah pasukan pemerhati pilihan raya ahli akademik yang lebih menyeluruh sebelum PRU-15 turut merupakan prospek yang boleh diteroka berdasarkan model yang telah dilaksanakan di Indonesia, Thailand dan Filipina. 
Selain sumber sekunder, makalah ini memperoleh keasliannya dengan pengalaman langsung kedua-dua penulis yang terlibat dalam pembentukan dan aktiviti pemerhatian pasukan pemerhati UKM dan juga beberapa PRK selepasnya. Sumber primer juga diperoleh menerusi temu bual dengan 20 informan yang terdiri daripada tiga bekas pengurusan tertinggi SPR, seorang bekas menteri kabinet dan komponen yang terbesar, aktivis dan anggota pemerhati yang terlibat dalam pemerhatian pilihan raya di Malaysia, Indonesia, Thailand dan Filipina.

\section{PENETAPAN KONTEKS: SISTEM PILIHAN RAYA DI MALAYSIA}

Malaysia telah mengadakan sebanyak 14 PRU sejak tahun 1955. Sepanjang era pemerintahan BN sehingga PRU-14, BN memperoleh kemenangan majoriti dua pertiga kerusi kecuali pada PRU-12 dan PRU-13. Fenomena ini berlaku akibat daripada gagasan politik baharu yang mula mengambil tempat pada PRU-10 (Loh 2005). Dalam PRU-14, kejutan besar berlaku apabila rejim BN tumbang di tangan PH. Salah satu sebab mengapa peralihan kuasa tidak diramalkan dengan meluas ialah kerana sistem pilihan raya yang dilihat sentiasa menyebelahi BN.

Semenjak penubuhannya, struktur organisasi SPR diletakkan di bawah pentadbiran Jabatan Perdana Menteri (JPM). Keadaan ini menyebabkan organisasi tersebut dilihat tidak benar-benar bebas (Weiss 2016). Wujudnya gesaan agar pelantikan ahli-ahli SPR dibuat menerusi parlimen dan pengubahsuaian prosedur-prosedur pilihan raya (Lim 2002). Kepimpinan SPR pula dikatakan tidak melaksanakan pilihan raya secara adil dan memberikan layanan yang tidak seimbang kepada parti-parti politik (Case 1993; Lim 2002; Muhammad Fathi et al. 2015). Teratas dalam hubungan ini ialah manipulasi urusan persempadanan seperti gerrymandering dan malapportionment bagi tujuan meningkatkan potensi kemenangan kepada BN termasuklah sebelum PRU-14 (Ostwald 2013; Washida 2018; Wong 2018; Muhamad Takiyuddin dan Muhamad Nadzri 2018). Selain itu, wujudnya ketidakseimbangan perbelanjaan pilihan raya antara calon penyandang dengan pembangkang. Perbezaan kekuatan kewangan yang ketara ini membolehkan BN mampu untuk melancarkan manifesto yang terarah kepada pembangunan, manakala pembangkang hanya berupaya untuk memperjuangkan amalan tadbir urus pentadbiran kerajaan yang baik di dalam kempen mereka (Ufen 2013).

Kawalan menyeluruh parti BN terhadap media cetak dan elektronik arus perdana membolehkannya memonopoli ruang media melalui penguasaan akhbarakhbar utama (Levitsky dan Way 2010). Dalam isu kerajaan sementara pula, empat cadangan dikemukakan iaitu menyekat kuasa pentadbiran eksekutif, penggunaan jentera kerajaan, perbelanjaan kerajaan untuk aktiviti politik dan kesamarataan hak parti-parti bertanding menggunakan ruang media kerajaan semasa berlangsungnya 
kempen (Muhammad Fathi 2014). Selain itu, berlakunya berbagai-bagai lagi kelemahan mikro seperti isu dakwat yang tidak kekal, undi pos yang dikeluarkan tidak menyeluruh kepada rakyat Malaysia yang berkelayakan (Ufen 2013) dan daftar pemilih semasa yang diguna pakai oleh SPR adalah tidak lengkap dan tidak terkini (Ong 2005).

Walaupun korpus kajian berkaitan pilihan raya adalah subur, kajian berhubung pemantauan pilihan raya masih terabai. Beberapa kajian hanya menyentuh mengenai pemantauan pilihan raya di Malaysia secara sepintas lalu dan tidak komprehensif seperti Hyde (2011), Khoo (2014), Wan Ahmad (2014) dan Muhamad Takiyuddin (2019). Justeru, selain menerokai secara preliminari kajian berhubung pemantauan pilihan raya di Malaysa, makalah ini juga cuba mengemukakan satu kajian kes berhubung keterlibatan pasukan pemerhati domestik dari sebuah organisasi baharu, iaitu ahli-ahli akademik.

\section{TAKRIFAN DAN IMPAK PEMANTAUAN PILIHAN RAYA}

Berakhirnya Perang Dingin dan konflik di negara-negara pascakolonial menyebabkan pilihan raya menjadi fokus penting dalam peralihan banyak negara ke sistem demokrasi. Selain meningkatkan latihan kepada parti-parti politik, promoter demokrasi dan badan-badan antarabangsa juga menghantar delegasi pemantauan pilihan raya bagi menilai pelaksanaan pilihan raya yang bersih dan adil.

Pemantau pilihan raya didefinisikan sebagai sekumpulan individu yang mempunyai autoriti untuk memerhati sesuatu proses pilihan raya dan membuat intervensi di dalam proses tersebut sekiranya undang-undang dan prosedur terlibat tidak dihiraukan atau dicabuli (International IDEA 1997, 9-10). Bjornlund (2004, 38-42) menyatakan terdapat tiga kategori pemantau pilihan raya, iaitu pemantau antarabangsa, pemantau domestik dan penyelia antarabangsa. Pemantau antarabangsa dikendalikan oleh sesuatu misi kerajaan, organisasi pelbagai hala dan NGO antarabangsa. Pemantau domestik pula kebiasaannya dianggotai oleh organisasi nasional, terutamanya NGO yang tidak memihak serta kumpulan sosial. Manakala penyelia antarabangsa pula terdiri daripada organisasi antara kerajaan lantikan Pertubuhan Bangsa-Bangsa Bersatu (PBB) yang menilai proses pilihan raya pascakonflik seperti Timor-Leste pada tahun 1999 dan Afghanistan pada tahun 2004. Penggunaan secara bersilih ganti istilah "pemantauan" dan "pemerhatian" bergantung pada dua elemen iaitu takat penglibatan dan tempoh masa yang terlibat dalam sesuatu proses. Pemantauan melibatkan aktiviti yang boleh melibatkan pencelahan sederhana bagi menambah baik. Ia berbentuk jangka panjang dan lebih substantif iaitu antara 6 hingga 18 bulan lebih awal. Pemerhatian pula secara relatifnya lebih berbentuk pasif iaitu hanya merakam dan melaporkan 
serta lebih memfokuskan hari pilihan raya (Magbul dan Zhvania 2004, 84; Lidauer dan Gil 2015, 3; Chandanie 2019).

Sehingga kini, Malaysia tidak pernah menjemput pemantau antarabangsa dalam setiap PRU yang diadakan. Hanya pada tahun 1990, kerajaan Malaysia menjemput pasukan pemerhati antarabangsa iaitu daripada Commonwealth Observer Group (COG) yang merupakan sebuah kumpulan pemerhati yang dilantik oleh Sekretariat Komanwel (Commonwealth 1990). Hyde (2011) mengesan bahawa negara seperti Malaysia dan Iran menongkah "norma antarabangsa" dalam jemputan terhadap pemantau antarabangsa berikutan tentangan tinggi khalayak domestik terhadap persoalan kedaulatan.

Selain pemantauan pilihan raya antarabangsa, trend yang subur secara beriringan dan menjadi tumpuan ialah pemantauan pilihan raya domestik atau dalam akronimnya, organisasi pemantau pilihan raya domestik (DEMOs). Terdapat dua kategori DEMOs iaitu pemantau pilihan raya domestik dan pemerhati pilihan raya domestik. Bjornlund $(2004,39)$ mengklasifikasikan DEMOs sebagai gabungan beberapa kumpulan NGO, kumpulan hak asasi manusia, persatuan profesional, pertubuhan khidmat masyarakat, pelajar-pelajar universiti dan pelbagai lagi. Mereka ini bekerjasama untuk memantau kelancaran pelaksanaan pilihan raya dan salah laku dalam pilihan raya. Lopez-Pintor (2004a, 3-9) pula menerangkan bahawa DEMOs merupakan gabungan sekumpulan masyarakat sivil yang menjalankan pemerhatian pemilihan di dalam negara asal mereka. Gromping (2017, 167-170) dengan itu melihat DEMOs lebih bersifat akar umbi, mempunyai hubungan secara top-down dengan pendana dan hubungan bottom-up dengan masyarakat. Antara DEMOs yang aktif adalah seperti Citizens Organized to Monitor Elections (GONG), International Society for Fair Elections and Democracy (ISFED), Media Monitoring (MEMO 98), National Citizens' Movement for Free Elections (NAMFREL), Electoral Assistance Bureau (EAB) dan Transparencia.

Peningkatan pemantau domestik berkembang dengan pesat sejak pertengahan tahun 1980-an khususnya dengan kejayaan NAMFREL dalam menumbangkan rejim Ferdinand Marcos di Filipina. The Global Network of Domestic Election Monitors (GNDEM) yang diasaskan pada tahun 2009 contohnya menaungi 175 organisasi dari 70 buah negara termasuk Afrika, Amerika Latin dan Asia (Norris 2017, 139). Banyak undang-undang pilihan raya juga telah dipinda bagi menjadikan kumpulan pemerhati domestik diinstitusikan dalam kerangka perundangan pilihan raya sesuatu negara (Lopez-Pintor 2004b). Terdapat tiga faktor yang membawa kepada pertumbuhan pesat DEMOs. Pertama, pemacu antarabangsa iaitu sokongan pendanaan daripada badan antarabangsa terhadap sektor NGO dan juga penyebaran difusi norma mengenai integriti pilihan raya. DEMOs umumnya tidak mempunyai kekuatan kewangan dan menyebabkan mereka perlu memperoleh sumber dana dari luar negara bagi membolehkan mereka beroperasi. Antara pendana yang aktif menyalurkan bantuan demokrasi adalah 
seperti International Foundation for Electoral Systems (IFES), International IDEA, National Democratic Institute (NDI), Carter Center dan Open Society Foundations (OSF). Kedua, kepercayaan bahawa perkumpulan sivik seperti DEMOs merupakan platform kepada pengembangan modal sosial. Terakhir dan yang terkini ialah kombinasi faktor rungutan dan struktur peluang (Gromping 2017, 169-174).

Pemerhati pilihan raya pula didefinisikan sebagai suatu kumpulan yang mengumpul informasi secara berhati-hati mengenai sesuatu proses pilihan raya, membuat penilaian yang jelas tentang pelaksanaan proses tersebut, dan tidak melampaui had pemerhatian terhadap proses berkenaan (International IDEA 1997, 10). Debre dan Morgenbesser (2017, 335-340) mengkategorikan pemerhati pilihan raya kepada dua kategori, iaitu kumpulan pemerhati profesional dan kumpulan pemerhati bayangan atau zombie. Kumpulan pemerhati profesional menjalankan pemerhatian secara telus, berpaksikan kepada kebebasan dan keadilan dalam pilihan raya dan laporan hasil pemerhatian sering kali memberi manfaat kepada parti-parti pembangkang. Manakala kumpulan pemerhati bayangan pula merupakan organisasi atau pertubuhan bukan kerajaan kelolaan kerajaan yang pro-pemerintah, berfungsi bagi memberi keabsahan sesuatu pengurusan pilihan raya dan berperanan sebagai opsyen kedua sesebuah rejim autoritarian bagi melaksanakan pelbagai manipulasi pilihan raya (Bush dan Prather 2017, 922; Merloe 2015, 86). Sungguhpun kebanyakan rejim autoritarian mengakui kepentingan pemantauan pilihan raya antarabangsa, namun dari segi praktisnya rejim berkenaan menggunakan pemantauan zombie di negara masing-masing (Cooley 2015, 54-55). Rejim juga melakukan pelbagai usaha bagi mengukuhkan pemerintahannya, antaranya seperti melemparkan tuduhan kepada kumpulan pemerhati profesional sebagai memihak kepada parti-parti tertentu dalam urusan pemerhatian yang dijalankan dan mengenakan pelbagai sekatan terhadap aktiviti mereka (Beaulieu dan Hyde 2009, 400).

Sama ada pemantau atau pemerhati pilihan raya, DEMOs mempunyai beberapa kelebihan. Pertama, DEMOs mempunyai pengetahuan luas mengenai negara dan politik dalam negara mereka sendiri dan boleh melihat banyak perkara yang tidak dapat dilihat oleh pemerhati antarabangsa dalam tempoh yang singkat. Kedua, berupaya untuk memobilisasi ramai sukarelawan untuk mendapat liputan pemantauan yang lebih luas. Ketiga, berupaya untuk mengakses ke tempat-tempat penting dalam proses pilihan raya. Keempat, melengkapkan peranan pemerhati pilihan raya antarabangsa dengan menawarkan kemudahan logistik (Carothers 1997; Goldman dan Pascual 1988, 230-231; Bjornlund 2004).

Begitu pun, impak DEMOs masih lagi bercampur baur dan bergantung kepada beberapa faktor. Biarpun kesan positif DEMOs terhadap pengurangan risiko penipuan telah dibuktikan (lihat Cecire 2013; Merloe 2015; Tunde, Mohd Azizuddin dan Ummu Atiyah 2016; Asunka et al. 2017), beberapa kajian juga menunjukkan kehadiran DEMOs tidak semestinya menjamin sokongan yang lebih 
baik bagi pencabar kuasa dan tidak memberi kesan substantif terhadap keputusan pilihan raya (lihat Benstead, Kao dan Lust 2015; Buzin, Brondum dan Robertson 2016; Skovoroda dan Lankina 2017). Terdapat beberapa faktor yang mengekang keberkesanan DEMOs. Teratas dalam hubungan ini ialah sifat memihak dan partisan. DEMOs sering kali dikaitkan dengan afiliasi politik dan kerap kali melakukan aktiviti yang mewakili kepentingan sesuatu parti politik. Selain itu, mereka juga kurang berkemahiran dan tidak terlatih dalam piawai integriti pilihan raya antarabangsa. Justeru, laporan mereka kurang memberi pemberat berbanding laporan pemantau antarabangsa atau serantau. Tanggapan sedemikian menyebabkan kurangnya sokongan daripada promoter demokrasi antarabangsa terhadap DEMOs (Carothers 1997; Ichino dan Schundeln 2012; Lynge-Mangueira 2012; Norris 2017). Malah, bagi pemantau terkemuka seperti NAMFREL, ia pernah dikritik kerana memaparkan sikap menyokong calon presiden Filipina, Gloria Macapagal Arroyo (Tadem 2007).

Faktor-faktor lain yang turut menjejaskan keberkesanan DEMOs ialah kurang mendapat sokongan kerajaan, di samping berlakunya penguatkuasaan undang-undang yang menyekat kebebasan dan urusan berkaitan pemerhatian (Chigudu 2015), kejayaan rejim untuk beradaptasi terhadap kehadiran DEMOs dengan melakukan manipulasi strategik (Sjoberg 2012), aktiviti pemantauan yang hanya menumpukan kepada pemantauan jangka pendek dan menyebabkan kekurangan data bagi menilai ketelusan sesuatu pilihan raya (Bjornlund 2004; Herron 2010), kemapanan sesuatu organisasi seperti kekurangan dana dan fokus yang tidak konsisten (Bjornlund 2004; Kuzel 2004) dan ancaman keselamatan dari rejim iaitu sekatan, gangguan dan penahanan (Merloe 2015).

\section{MEMPOSISIKAN KEDUDUKAN PASUKAN PEMERHATI AHLI AKADEMIK DALAM PEMERHATIAN PILIHAN RAYA DI MALAYSIA}

Peruntukan undang-undang pilihan raya di Malaysia sedia ada tidak menyentuh mengenai pelantikan dan keterlibatan aktiviti pemantau atau pemerhati pilihan raya sama ada dalam Akta Pilihan Raya 1958 dan Peraturan-Peraturan Pilihan Raya (Penjalanan Pilihan Raya) 1981. SPR menggunakan definisi pemerhati pilihan raya yang umum sama ada bagi pemerhati dari dalam dan luar negara. Ia mendefinisikan pemerhati pilihan raya sebagai sekumpulan individu yang menjalankan pengumpulan maklumat secara sistematik, tepat dan komprehensif. Analisis pelaporan yang disediakan mereka pula adalah bersifat berkecuali dan tidak menyebelahi mana-mana pihak (Suruhanjaya Pilihan Raya 2018). Terma berkecuali ini menjadi asas mengapa pemerhati pilihan raya perlu dibezakan dengan ejen-ejen parti politik yang turut menghadiri sesuatu proses pengundian 
dan pengiraan (PACABA) kerana kedudukan mereka yang mewakili parti tertentu (Lidauer dan Gil 2015, 2).

Aktiviti DEMOs di Malaysia boleh dibahagikan kepada dua bentuk iaitu pemantauan (bebas dan tidak dilantik oleh SPR) dan pemerhatian (menerima akreditasi daripada SPR). Seperti yang ditunjukkan dalam Jadual 1, data menemukan 16 badan pemantau bebas yang bergerak sejak tahun 1990 hingga 2018. Walau bagaimanapun, sebahagian daripada badan ini wujud secara bermusim seperti item 11-16. Bagi pemerhati pilihan raya domestik rasmi, Malaysian for Free and Fair Elections (MAFREL) merupakan badan terawal yang dilantik secara rasmi bagi pelaksanaan PRU-12 dan menjalankan pemerhatian dalam lapan PRK antara tahun 2004 hingga 2008. SPR melalui inisiatif timbalan pengerusinya ketika itu, Wan Ahmad kemudiannya mengambil langkah penting dengan memberi akreditasi kepada 17 NGO untuk terlibat dalam pelaksanaan PRU-13 dengan diwakili oleh 1,200 pemerhati (Suruhanjaya Pilihan Raya 2013, 49; Wan Ahmad 2018). Daripada jumlah tersebut, lapan NGO dilantik semula bersama-sama dengan enam badan baharu dalam PRU-14 (Suruhanjaya Pilihan Raya 2018). Keanggotaan pemerhati rasmi bertambah dengan lebih variasi selepas PRU-14. Rombakan terhadap SPR di bawah kerajaan PH menyaksikan penglibatan badan-badan yang sebelumnya tidak dibenarkan atau ditolak untuk terlibat sebagai pemerhati rasmi seperti BERSIH, Suruhanjaya Hak Asasi Manusia Malaysia (SUHAKAM), ENGAGE dan Tindak Malaysia bermula daripada PRK pertama selepas PRU-14, iaitu Sungai Kandis. SPR juga mula membuka secara terbuka permohonan untuk terlibat sebagai pemerhati pilihan raya berbanding pemilihan yang dibuat secara tertutup, di atas permintaan dan cenderung memilih NGO yang tidak kritikal.

Walaupun penyertaan pasukan ahli akademik sebagai pasukan pemerhati pilihan raya merupakan sesuatu yang baharu di Malaysia, ia merupakan praktik yang telah dilaksanakan di beberapa negara Asia Tenggara. Dalam kes Indonesia, dua badan awal yang berkaitan ialah University Network for Free and Fair Election (UNFREL) dan Rektor Forum yang menyertai Pemilihan Umum (PEMILU) 2004 iaitu pilihan raya umum pertama yang diadakan selepas kejatuhan rejim Suharto pada tahun 1998. UNFREL diselaraskan oleh ahli akademik di Universiti Indonesia dan Rektor Forum pula digerakkan oleh ratusan rektor pengajian tinggi seluruh Indonesia. Ia bukan sahaja diselaras dan disertai ahli akademik, namun turut dianggotai mahasiswa (Bjornlund 2004; Hadar Nafis 2019). Di Thailand pula, pasukan We Watch yang diselaraskan oleh ahli akademik dan digerakkan oleh mahasiswa turut ditubuhkan dalam memantau pilihan raya umum 2019 iaitu pilihan raya pertama yang berlangsung selepas rampasan kuasa tentera pada tahun 2014 (Prajak 2019). 
Jadual 1: Penyertaan badan pemantau bebas dan badan pemerhati rasmi pilihan raya domestik di Malaysia antara PRU-8 hingga enam siri PRK pasca PRU-14

\begin{tabular}{|c|c|c|c|}
\hline \multirow{2}{*}{ Bil. } & \multirow{2}{*}{ Badan pemantau bebas } & \multicolumn{2}{|c|}{ Badan pemerhati rasmi lantikan SPR } \\
\hline & & Pertubuhan bukan kerajaan & Organisasi akademik \\
\hline 1. & Election Watch (PRU-8) & MAFREL (PRU-12) & $\begin{array}{l}\text { UKM (PRU-14 dan PRK } \\
\text { Sungai Kandis, Balakong } \\
\text { Port Dickson dan } \\
\text { Cameron Highlands) }\end{array}$ \\
\hline 2. & $\begin{array}{l}\text { Pemantau Pilihan } \\
\text { Raya Rakyat Malaysia } \\
\text { (PERMANTAU) (PRU-10) }\end{array}$ & Merdeka Center (PRU-13) & UiTM (PRU-14) \\
\hline 3. & $\begin{array}{l}\text { Pemantau Pilihan Raya } \\
\text { Rakyat (PEMANTAU) } \\
\text { (PRU-13 dan PRU-14) }\end{array}$ & $\begin{array}{l}\text { Institute for Democracy } \\
\text { and Economic Affairs } \\
\text { (IDEAS) (PRU-13) }\end{array}$ & UniKL (PRU-14) \\
\hline 4. & $\begin{array}{l}\text { MAFREL (PRU-13 dan } \\
\text { PRU-14) }\end{array}$ & $\begin{array}{l}\text { Gabungan Persatuan Orang } \\
\text { Cacat Malaysia (PRU-13) }\end{array}$ & \\
\hline 5. & $\begin{array}{l}\text { BERSIH (PRU-13 dan } \\
\text { PRU-14) }\end{array}$ & $\begin{array}{l}\text { Persatuan Belia Islam } \\
\text { Nasional Cawangan } \\
\text { Sarawak (PEMBINA } \\
\text { Sarawak) (PRU-13) }\end{array}$ & \\
\hline 6. & $\begin{array}{l}\text { Pusat Komunikasi } \\
\text { Masyarakat (Pusat KOMAS) } \\
\text { (PRU-13 dan PRU-14) }\end{array}$ & $\begin{array}{l}\text { Majlis Belia Malaysia } \\
\text { (MBM) (PRU-13 dan } \\
\text { PRU-14) }\end{array}$ & \\
\hline 7. & $\begin{array}{l}\text { Suara Rakyat Malaysia } \\
\text { (SUARAM) (PRU-14) }\end{array}$ & $\begin{array}{l}\text { Centre for Public Policy } \\
\text { Studies (CPPS) (PRU-13) }\end{array}$ & \\
\hline 8. & SUHAKAM (PRU-14) & $\begin{array}{l}\text { Persatuan Sejarah } \\
\text { Malaysia Sabah (PRU-13) }\end{array}$ & \\
\hline 9. & $\begin{array}{l}\text { National Institute for } \\
\text { Electoral Integrity (NIEI) } \\
\text { (PRU-10, PRU-11 dan } \\
\text { PRU-12) }\end{array}$ & $\begin{array}{l}\text { Majlis Belia Sabah (MBS) } \\
\text { (PRU-13 dan PRU-14) }\end{array}$ & \\
\hline 10. & $\begin{array}{l}\text { Centre for Independent } \\
\text { Journalism (CIJ) (PRU-12 } \\
\text { dan PRU-13) }\end{array}$ & $\begin{array}{l}\text { Gabungan Persatuan Cina } \\
\text { Sabah (PRU-13) }\end{array}$ & \\
\hline 11. & $\begin{array}{l}\text { Malaysian Voters' Union } \\
\text { (MALVU) (PRK pasca } \\
\text { PRU-10) }\end{array}$ & $\begin{array}{l}\text { Dayak Bidayuh National } \\
\text { Association (DBNA) } \\
\text { (PRU-13 dan PRU-14) }\end{array}$ & \\
\hline
\end{tabular}

(bersambung) 
Jadual 1 (sambungan)

\begin{tabular}{|c|c|c|c|}
\hline \multirow{2}{*}{ Bil. } & \multirow{2}{*}{ Badan pemantau bebas } & \multicolumn{2}{|c|}{ Badan pemerhati rasmi lantikan SPR } \\
\hline & & Pertubuhan bukan kerajaan & Organisasi akademik \\
\hline 12. & $\begin{array}{l}\text { Sarawakians for Free and } \\
\text { Fair Elections (SAFREL) } \\
\text { (PRK pasca PRU-10) }\end{array}$ & $\begin{array}{l}\text { Persatuan Kebangsaan } \\
\text { Melayu Sarawak (PKMS) } \\
\text { (PRU-13 dan PRU-14) }\end{array}$ & \\
\hline 13. & $\begin{array}{l}\text { Malaysia Election } \\
\text { Observation Network (MEO- } \\
\text { Net) (PRK pasca PRU-10) }\end{array}$ & $\begin{array}{l}\text { Orang Ulu National } \\
\text { Association (OUNA) } \\
\text { (PRU-13 dan PRU-14) }\end{array}$ & \\
\hline 14. & $\begin{array}{l}\text { My Election Watch (MEW) } \\
\text { (PRK pasca PRU-10) }\end{array}$ & $\begin{array}{l}\text { Sibu Chinese Chamber of } \\
\text { Commerce and Industry } \\
\text { (SCCCI) (PRU-13 dan } \\
\text { PRU-14) }\end{array}$ & \\
\hline 15. & $\begin{array}{l}\text { Sibu Election Watch (SEW) } \\
\text { (PRK pasca PRU-10 }\end{array}$ & $\begin{array}{l}\text { Persatuan Melanau Sibu } \\
\text { (PRU-13 dan PRU-14) }\end{array}$ & \\
\hline 16. & $\begin{array}{l}\text { Movement for Change } \\
\text { Sarawak (MoCS) (Pilihan } \\
\text { Raya Negeri Sarawak } 2011 \\
\text { dan 2016; PRU-13 dan } \\
\text { PRU-14) }\end{array}$ & $\begin{array}{l}\text { Persatuan Cina Miri (PRU- } \\
13 \text { dan PRU-14) }\end{array}$ & \\
\hline 17. & & $\begin{array}{l}\text { Federation of Orang Ulu } \\
\text { Association Malaysia } \\
\text { (FORUM) (2013) }\end{array}$ & \\
\hline 18. & & $\begin{array}{l}\text { Persatuan Dayak Miri } \\
\text { (DAM) (2013) }\end{array}$ & \\
\hline 19. & & $\begin{array}{l}\text { Persatuan Pengundi } \\
\text { Wawasan Malaysia Kuala } \\
\text { Lumpur (PPWMKL) } \\
\text { (2018) }\end{array}$ & \\
\hline 20. & & $\begin{array}{l}\text { Persatuan Orang Kota } \\
\text { Bharu (POKB) (2018) }\end{array}$ & \\
\hline 21. & & $\begin{array}{l}\text { Dewan Perniagaan } \\
\text { Bumiputera Sabah (DPBS) } \\
(2018)\end{array}$ & \\
\hline
\end{tabular}


Jadual 1 (sambungan)

\begin{tabular}{|c|c|c|c|}
\hline \multirow{2}{*}{ Bil. } & \multirow{2}{*}{ Badan pemantau bebas } & \multicolumn{2}{|c|}{ Badan pemerhati rasmi lantikan SPR } \\
\hline & & Pertubuhan bukan kerajaan & Organisasi akademik \\
\hline \multicolumn{4}{|c|}{ Penyertaan Pasca PRU-14 } \\
\hline 1. & & $\begin{array}{l}\text { SUHAKAM (PRK Sungai } \\
\text { Kandis) }\end{array}$ & UIAM (PRK Seri Setia) \\
\hline 2. & & BERSIH (kesemua PRK) & $\begin{array}{l}\text { IDE (PRK Seri Setia, } \\
\text { Port Dickson Cameron } \\
\text { Highlands dan Semenyih) }\end{array}$ \\
\hline 3. & & $\begin{array}{l}\text { Kelab Pemikir Politik } \\
\text { Nasional (KPPN) } \\
\text { (kesemua PRK) }\end{array}$ & UM (PRK Semenyih) \\
\hline 4. & & ENGAGE (kesemua PRK) & \\
\hline 5. & & $\begin{array}{l}\text { Jawatankuasa Khas } \\
\text { Pembaikan Sistem dan } \\
\text { Undang-undang Pilihan } \\
\text { Raya (ERC) (kesemua } \\
\text { PRK kecuali Sungai } \\
\text { Kandis) }\end{array}$ & \\
\hline 6. & & $\begin{array}{l}\text { Persatuan Orang Kurang } \\
\text { Upaya Sentral (OKU } \\
\text { Sentral) (kesemua PRK } \\
\text { kecuali Sungai Kandis dan } \\
\text { Port Dickson) }\end{array}$ & \\
\hline 7. & & $\begin{array}{l}\text { Dewan Perhimpunan } \\
\text { Cina Kuala Lumpur \& } \\
\text { Selangor (KLSCAH) (PRK } \\
\text { Balakong) }\end{array}$ & \\
\hline 8. & & $\begin{array}{l}\text { Tindak Malaysia (PRK } \\
\text { Cameron Highlands dan } \\
\text { Semenyih) }\end{array}$ & \\
\hline 9. & & $\begin{array}{l}\text { Pertubuhan Akademi } \\
\text { Pendidikan Demokrasi } \\
\text { dan Kewarganegaraan } \\
\text { Malaysia (APDK) (PRK } \\
\text { Cameron Highlands dan } \\
\text { Semenyih) }\end{array}$ & \\
\hline
\end{tabular}

(bersambung) 
Jadual 1 (sambungan)

\begin{tabular}{ll}
\hline \multirow{2}{*}{ Bil. $\quad$ Badan pemantau bebas } & \multicolumn{1}{c}{ Badan pemerhati rasmi lantikan SPR } \\
\cline { 2 - 2 } 10. & Pertubuhan bukan kerajaan $\quad$ Organisasi akademik \\
\hline & Malaysian Corruption \\
& Cameron Highlands dan \\
& Semenyih) \\
11. & MAFREL (PRK Cameron \\
& Highlands dan Semenyih) \\
12. & Malaysian Indian Voters \\
& (MIV) (PRK Semenyih) \\
\hline
\end{tabular}

Nota: Jadual diubah suai daripada Funston (2000); Case (2004); PEMANTAU (2014); Khoo (2016); Saravanamuttu (2016); Malaysiakini (2017); Commonwealth (1990); The Malay Mail Online (2017); Suruhanjaya Pilihan Raya (2013; 2018; 2019); Loh (2010); Muhamad Takiyuddin (2019); Weiss (2000); Francis Paul (2019); Irwan Shafrizan dan Kannan (2018).

Dalam kes Malaysia, permulaan penglibatan pasukan ahli akademik sebagai pemerhati pilihan raya boleh dianggap berlaku atas faktor kebetulan melalui inisiatif yang dimulakan oleh Pusat Pengajian Sejarah, Politik dan Strategi (PPSPS, kini Pusat Dasar dan Governans Global) UKM. Idea untuk membentuk pasukan pemerhati universiti dicetuskan oleh kedua-dua penulis apabila melakukan kajian mengenai bidang pemantauan pilihan raya di Malaysia. Idea awal yang difikirkan ialah untuk melakukan pemerhatian secara tidak rasmi menerusi kajian lapangan pilihan raya. Namun, pemerhatian secara tidak rasmi tidak dapat memberi akses penuh terhadap perjalanan pilihan raya. Justeru, permohonan dibuat kepada pihak SPR untuk menyertai pemerhatian rasmi PRU14 atas tiket universiti. Dalam hubungan ini, kredit harus diberi kepada bekas Pengerusi SPR, Mohd Hashim Abdullah (2016-2018) yang sememangnya sedang memikirkan langkah untuk melibatkan pihak universiti dalam proses pilihan raya. Justeru, selain meluluskan permohonan PPSPS UKM, SPR juga menawarkan tempat kepada dua universiti lain yang memaparkan "kesungguhan" untuk terlibat dan telah mempunyai jaringan dengan SPR iaitu UiTM (diwakili oleh Fakulti Komunikasi dan Pengajian Media) dan UniKL (Mohd Hashim 2019).

Persoalan yang wajar dikemukakan ialah mengapa pasukan pemerhati ahli akademik tidak dilibatkan lebih awal sebagai pemerhati pilihan raya? Dalam hubungan ini, kita harus kembali kepada pempolitikan akademia yang berlaku dengan meluas di bawah rejim BN. Sekian lama, golongan akademik dan intelektual di instituti pengajian tinggi Malaysia boleh dianggap terpecah kepada dua kelompok, iaitu golongan yang pro-BN dan golongan yang mengambil pendirian kritikal ataupun pro-demokrasi. Beberapa kes campur tangan dan tekanan yang dikenakan terhadap ahli akademik khususnya mereka yang mengkhusus dalam 
kajian politik dan pilihan raya telah meluas diperbahaskan mengambil contoh P. Ramasamy, Edmund Terence Gomez, Azmi Sharom dan Redzuan Othman. Timbalan Pengerusi SPR, Wan Ahmad Wan Omar (2018) turut melihat, "masa zaman saya, universiti (dan) beberapa ahli akademik yang terlibat dalam urusan politik pilihan raya dilihat oleh kerajaan (ketika itu) lebih condong kepada parti pembangkang, saya rasa itu perasaan orang dalam kerajaanlah".

Memandangkan majoriti ahli akademik dilihat mengambil pendirian menyokong pemerintah sedia ada ketika itu - contoh terbaik ialah Majlis Profesor Negara (MPN) yang dianggap sebagai tangki intelektual BN - timbulnya keraguan bahawa laporan pemerhatian yang dikeluarkan oleh ahli-ahli akademik seperti ini tidak mampu bersikap kritis terhadap salah laku yang mungkin wujud (Paul 2019).

Bahagian selanjutnya akan menerangkan kelebihan yang dipunyai pasukan pemerhati ahli akademik berbanding pemerhati pilihan raya tradisional, iaitu NGO dan juga kekangan dan cabaran yang dihadapi dalam pengoperasiannya. UKM akan dijadikan kajian kes khusus dalam hubungan ini kerana beberapa sebab. Pertama, kedudukannya sebagai universiti yang menjadi perintis terhadap kumpulan pemerhati akademik bermula daripada PRU-14. Kedua, bagi menerangkan kekangan yang dihadapi oleh sesebuah universiti awam dan kaitannya dengan persoalan partisan. Ketiga, berbanding UniKL dan UiTM yang turut menyertai pemerhatian PRU-14, komitmen UKM dilihat konsisten kerana ia terus terlibat dengan beberapa siri pemerhatian dalam PRK pasca PRU-14. Berbanding dua universiti perintis yang lainnya juga, UKM merupakan satu-satunya universiti yang menghantar laporan penuh dan dihantar tepat pada masanya (Mohd Shukur 2019). UIAM pula hanya meyertai PRK Seri Setia dan hanya diwakili oleh tiga orang anggota yang merupakan pembantu penyelidik. UM dalam pada itu hanya menyertai PRK Semenyih dan dianggap masih baharu. IDE walaupun menyertai empat siri PRK selepas PRU-14 turut tidak diberi tumpuan kerana kedudukannya yang dekat dengan kerajaan Negeri Selangor pimpinan Parti Keadilan Nasional (PKR) dan berpotensi mewujudkan masalah bias. Berdasarkan fakta-fakta ini, UKM berada dalam kedudukan baik untuk dijadikan kajian kes khusus.

\section{KELEBIHAN PASUKAN PEMERHATI PILIHAN RAYA AHLI AKADEMIK}

Kelebihan pertama pasukan pemerhati pilihan raya akademik ialah kerana latar mereka yang berkelayakan. Dengan tingkat akademik yang dipunyai mereka, ia dapat mengelakkan fenomena keanggotaan tangkap muat yang sering berlaku dalam kumpulan pemerhati yang lain (Azuwan 2018; Mohamed Zain 2018). Faktor kelayakan dan kompetensi anggota pemerhati merupakan antara masalah universal yang berlaku dalam banyak kes pasukan DEMOs. Analisis pelaporan daripada 
16 borang soal selidik anggota pemerhati UKM dalam PRU-14 mendapati komen terbanyak yang dicatatkan oleh ahli pasukan ialah kompetensi anggota pasukan pemerhati lain iaitu $f=7$. Menurut mereka, SPR harus melantik pemerhati yang berkredibiliti seperti ahli-ahli akademik yang bebas kepentingan, kritikal dan menilai berdasarkan ilmu dan kepakaran yang mereka miliki. Hal ini menurut mereka dapat memberi input yang lebih baik kepada SPR. Ramai anggota UKM melihat beberapa DEMOs tidak kompeten untuk menjalankan tugas mereka kerana dipilih sekadar tangkap muat, tidak tahu organisasi yang mereka wakili, memakai seluar jeans dan kemeja-T sewaktu melakukan pemerhatian, kurang berpendidikan dan merupakan ahli parti. Malah, ada yang mencadangkan agar pemerhati universiti juga perlu diasingkan daripada pemerhati biasa (NGO). Dalam kes pasukan UKM umpamanya, sebahagian besar mereka berkelulusan sarjana dan $\mathrm{PhD}$. Sebahagian besar mereka juga telah terlibat dengan kajian berkaitan politik dan sejarah pilihan raya. Kelebihan seperti ini merupakan nilai tambah penting dalam menjamin kualiti pemerhatian dan mutu laporan yang dihasilkan kerana pasukan ahli akademik mempunyai fokus yang jelas, "metodologi" yang sesuai dan melihat dengan "lebih mendalam" berbanding pemerhati lain (K. Shan 2019).

Selain itu, reputasi non-partisan juga dihujahkan turut mengukuhkan kredibiliti pasukan ahli akademik dengan syarat pemilihan anggota pasukan dibuat secara ketat dan mengutamakan mereka yang diketahui tidak mempunyai kecenderungan politik yang begitu jelas. Kami menggunakan istilah "kecenderungan politik yang begitu jelas" kerana sememangnya persoalan bias dan neutraliti turut merupakan perkara yang subjektif. Sarjana dan aktivis mengakui untuk mencari sebuah pasukan pemerhati yang seratus peratus neutral adalah mustahil memandangkan setiap ahli pasukan pemerhati juga mempunyai kecenderungan politik tertentu (Callahan 2000; Chandanie 2019). Namun seperti yang dihujahkan oleh seorang sarjana, "monitors must be non-partisan and must be seen to be non-partisan" (Lopez-Pintor 2004b, 114). Seperti yang telah dijelaskan sebelum ini, antara masalah utama DEMO's ialah sikap memihak dan bertugas untuk kepentingan parti dan etnik tertentu. Di Malaysia, keadaan ini lebih jelas dirasakan sehinggalah selepas PRU-14 apabila kebanyakan badan pemerhati yang terlibat mempunyai afiliasi politik atau kepentingan tertentu. Jadual 2 menggalurkan beberapa afiliasi utama beberapa DEMOs terpilih.

Selain itu, syarat SPR bahawa pemerhati tidak boleh menjadi ahli mana-mana politik adalah longgar kerana wujudnya bukti bahawa sebahagian mereka merupakan ahli parti politik. Biarpun SPR memaklumi reputasi partisan ini dan tidak pernah menjadikannya sebagai satu halangan (Wan Ahmad 2018; Abdul Rashid 2019), namun ia tetap mempunyai implikasi tertentu terhadap hasil pemerhatian. Justeru, kewujudan reputasi partisan seperti ini boleh diminimumkan dengan penglibatan pasukan pemerhati universiti. Dalam kes UKM, pasukan UKM yang ditubuhkan dipilih sendiri oleh penulis pertama bagi 
memastikan ia diwakili oleh mereka yang berkredibiliti dan tidak partisan. Dalam keadaan di mana pasukan pemerhati domestik (sama ada yang dilantik SPR ataupun pemerhati bebas) dilihat mempunyai reputasi partisan masing-masing, pasukan pemerhati universiti boleh mengisi lompong berhubung penghasilan laporan pemerhatian yang seimbang, neutral dan tidak memihak. Menurut pegawai kanan SPR, Mohd Shukur Khalid (2019):

Bila saya tengok (laporan soal selidik yang dipulangkan oleh UKM), pandangan mereka lebih terbuka (berbanding laporan) NGO tertentu yang (agak kedekut dengan pujian dan kredit dan hanya tahu mencari kesalahan). (Laporan pemerhati seperti UKM) simple, clear cut. You buat bagus, bagus. You buat tak bagus, tak bagus.

Pasukan pemerhati UM yang mula menyertai PRK Semenyih pula diketuai dan diwakili oleh ahli-ahli akademik yang terdiri daripada tenaga muda dan dilihat tidak mempunyai sebarang kecenderungan tertentu berbanding beberapa ahli akademik kanan yang sebelum ini secara jelas mengambil pendirian memihak.

Jadual 2: Afiliasi utama beberapa DEMOs terpilih di Malaysia

\begin{tabular}{rll}
\hline Bil. & Pertubuhan & Afiliasi utama \\
\hline 1. & BERSIH & $\begin{array}{l}\text { Bekerjasama dengan parti politik PH sejak awal penubuhannya } \\
\text { dan bersifat antirejim. Ramai barisan kepimpinan kini berada atau } \\
\text { bertugas dengan PH. }\end{array}$ \\
& & $\begin{array}{l}\text { PKR (melalui dua pengerusi sebelum ini, iaitu Abdul Malik Hussin } \\
\text { dan Syed Ibrahim Syed Noah) }\end{array}$ \\
2. & MAFREL & PKR (kepimpinan Amin Shah Iskandar) \\
3. & NIEI & BN \\
4. & MBM/MBS & BN \\
5. & PPWMKL & PKR (menerusi Angkatan Belia Islam Malaysia [ABIM]) \\
6. & APDK & BN \\
7. & KPPN & Parti Pribumi Bersatu Malaysia (BERSATU) \\
8. & MCW & PKR \\
9. & IDE & BERSATU \\
10. & ERC & Malaysian Indian Congress (MIC) \\
11. & MIV &
\end{tabular}

Nota: Sebahagian besar maklumat ini diubah suai daripada Azuwan (2018); Muhamad Takiyuddin dan Muhamad Nadzri (2018); Muhamad Takiyuddin (2019); Chandra (2019); Arphan (2019); K. Shan (2019); Rafidi (2019); Jais (2019) dan juga pemerhatian kajian lapangan kedua-dua penulis. 
Selain itu, kewujudan pasukan pemerhati pilihan raya akademik juga boleh mengatasi masalah kemapanan yang merupakan antara masalah penting DEMOs dalam kalangan NGO di Malaysia. Memandangkan ahli akademik terlibat dalam proses penyelidikan dan pengajaran pada setiap masa, ia memberikan lebih insentif kepada mereka untuk terus terlibat dalam disiplin ini. Ketidakaktifan dan kemalapan beberapa DEMOs di Malaysia seperti MAFREL, NIEI dan berbagaibagai lagi badan pemerhati bermusim merupakan indikasi jelas mengenai trend kelestarian DEMOs di Malaysia.

\section{CABARAN PASUKAN PEMERHATI PILIHAN RAYA AKADEMIK}

Cabaran teratas seperti yang dihadapi UKM dalam PRU-14 ialah campur tangan pihak pengurusan universiti. Setelah pembentukan dan pemilihan ahli pasukan yang dilakukan penulis, wujudnya campur tangan daripada pihak pengurusan tertinggi yang mengakibatkan berlakunya beberapa perubahan substantif daripada aspek pelantikan penyelaras dan kemasukan ahli pasukan yang dilihat lebih pro kepada rejim BN. Salah seorang nama asal ahli pasukan juga digugurkan kerana dilaporkan mempunyai "kes". Kesemua perubahan ini dilakukan tanpa sebarang rundingan dan berbentuk sehala. Pada akhirnya, pasukan pemerhati UKM yang dianggotai oleh 18 orang seakan-akan berpecah kepada dua kelompok. Selepas PRU-14, majoriti anggota pasukan UKM yang asal enggan meneruskan penglibatan dalam beberapa siri PRK selepas itu dan UKM hanya diwakili oleh empat hingga lima ahli dan dilakukan atas kapasiti formaliti.

Sokongan dana dan logistik daripada pihak universiti juga penting bagi memastikan idea pasukan pemerhati universiti dapat dilaksanakan. Masalah dana merupakan masalah penting yang bukan sahaja berlaku dalam pasukan pemerhati akademik, namun kepada keseluruhan DEMOs. Kebanyakan pemerhati pilihan raya domestik di Malayaia bergerak dengan dana sendiri dan ada juga yang menerima bantuan dana daripada pelbagai promoter demokrasi luar yang merupakan aktor utama dalam bantuan pilihan raya. Dalam PRU-13, SPR memperuntukkan dana antara RM30,000 hingga RM50,000 terhadap badan pemerhati rasmi (Wan Ahmad 2018). Peruntukan yang sama tidak diberikan kepada badan pemerhati bagi PRU-14 dan siri PRK selepasnya di mana antara syarat bagi pasukan pemerhati ialah semua perbelanjaan proses pemerhatian harus ditanggung oleh organisasi pemerhati.

Walaupun pasukan UKM pernah memohon dana one-off daripada UKM bagi tugasan dalam PRU-14, permohonan ini tidak menerima respons positif. Kebanyakan ahli menggunakan peruntukan atau geran penyelidikan sendiri. Ketiadaan dana ini menyebabkan pasukan UKM tidak dapat mengambil bilangan ahli yang lebih ramai dan memperluaskan cakupan pemerhatian. Ahliahli pemerhati juga dipilih berdasarkan kawasan di mana mereka mengundi bagi 
membolehkan impak ketiadaan dana dapat diminimumkan - suatu pendekatan yang turut dilaksanakan oleh badan pemerhati lain seperti IDEAS dalam PRU-13 (Amir Ridzuan 2019). Walaupun banyak cadangan daripada DEMOs agar SPR memperuntukkan dana khusus bagi tujuan pemerhatian, penerimaan dana daripada organisasi penyelenggara pilihan raya juga berpotensi menimbulkan kepentingan konflik dan memberi kesan terhadap kebebasan sesuatu DEMOs. Justeru, dalam hubungan ini, dana daripada pihak universiti dalam bentuk geran penyelidikan merupakan alternatif yang lebih baik. Wujudnya konsensus dalam majoriti anggota pemerhati universiti yang pasukan pemerhati bukanlah memerlukan satu dana yang besar. Memahami kekangan kewangan yang dihadapi pihak universiti dalam keadaan semasa, bantuan yang mereka inginkan hanyalah dana kecil bagi menandakan sokongan pihak universiti. Sokongan logistik seperti kenderaan dan pembantu penyelidik khusus juga merupakan antara perkara yang boleh dipertimbangkan universiti dalam hubungan ini (Shamsinor 2019).

Berbanding pasukan khusus yang mewakili institusi pengajian tertentu, pengwujudan sebuah pasukan pemerhati universiti yang terdiri daripada ahli akademik (sama ada awam ataupun swasta) seperti yang pernah dilaksanakan Rektor Forum di Indonesia turut merupakan satu keperluan yang boleh dipertimbangkan. Dengan keahlian yang lebih besar, pasukan ini mampu menembusi skop cakupan pemerhatian yang lebih luas kerana kewujudan institusi pengajian di setiap negeri di Malaysia. Tidak semua pasukan pemerhati universiti boleh bertugas di sesuatu kawasan dengan keterbatasan dana dan sokongan universiti. Sebagai contoh, apabila berlakunya PRK Parlimen Sandakan pada Mei 2019, SPR masih menjemput pasukan pemerhati yang kesemuanya berpengkalan di Semenanjung termasuklah beberapa pasukan universiti. Hal ini merupakan sesuatu yang tidak praktikal kerana kos penerbangan dan kos pengangkutan yang terlibat kepada badan pemerhati. Dengan kewujudan pasukan pemerhati universiti, wakil daripada institusi pengajian yang berdekatan seperti Universiti Malaysia Sabah (UMS) dan UiTM Sabah boleh ditugaskan untuk bertindak sebagai pemerhati. Selain meminimumkan kos perbelanjaan, ia juga memberi nilai tambah penting kerana idealnya pemerhatian pilihan raya domestik harus dijalankan oleh komuniti tempatan yang lebih memahami masalah, budaya dan selok-belok sesuatu kawasan.

Namun begitu, cabaran tetap wujud dalam melaksanakan idea ini. Pengalaman penulis pertama yang pernah terlibat dalam sebuah majlis perundingan jabatan pengajian antara universiti mendapati ia akhirnya mati begitu sahaja kerana kelemahan penyelarasan, sikap ego dalam kalangan universiti, kekurangan sokongan pengurusan tertinggi dan ketiadaan dana khusus bagi menjalankan aktiviti. Justeru, antara ciri penting pasukan pemerhati universiti ini ialah ia harus diurus dan dianggotai mereka yang relatifnya muda. Dalam kes UKM, majoriti ahli akademik yang dipilih merupakan mereka yang relatifnya muda. 
Selain meminimumkan politiking yang berlaku apabila ia diuruskan oleh ahliahli akademik yang amat kanan, komposisi keahlian yang muda ini menyumbang kepada komitmen tugas yang lebih baik dan mudah diuruskan.

Terakhirnya, komposisi pasukan pemerhati pilihan raya akademik harus melibatkan penglibatan mahasiswa. Sehingga setakat ini, mahasiswa masih tidak dilibatkan dalam mana-mana pasukan pemerhati ahli akademik. Hal ini berbeza dengan badan pemerhati akademik seperti di Indonesia dan Thailand yang majoritinya melibatkan mahasiswa. Apabila bekas Pengerusi SPR, Mohd Hashim Abdullah membuka penyertaan kepada pasukan universiti, rancangan asalnya agar ia turut melibatkan pelajar dan penyertaan mereka diharapkan dapat memberi kesan berantai terhadap peningkatan pendaftaran pengundi muda (2019). Di Universitas Gadjah Mada, penyertaan mahasiswa sebagai pemerhati pilihan raya turut dilakukan bagi memenuhi kredit latihan industri (latihan praktikal) jika masanya bertepatan dengan keperluan sesuatu pilihan raya. Sebuah badan pemerhati pilihan raya Filipina, Legal Network for Truthful Elections (LENTE) juga bekerjasama dengan institusi pengajian tinggi di Filipina dalam merekrut sukarelawan dalam kalangan mahasiswa bagi Pilihan Raya Presiden 2016 (Ona 2019). Namun, menurut Setiausaha Kehormat NAMFREL di Filipina, penglibatan pelajar seboleh-bolehnya haruslah dibataskan kepada aspek-aspek bukan teknikal seperti mengambil gambar, dokumentasi dan sebagainya. Hal ini kerana kekurangan pengalaman mereka dibimbangi akan menjejaskan ketepatan proses pemerhatian (Alvia 2019).

\section{KESIMPULAN DAN IMPLIKASI}

Bidang pemantauan pilihan raya di Malaysia merupakan sebuah bidang yang terabai dalam kajian berhubung sistem pilihan raya. Makalah ini merupakan sumbangan preliminari untuk meneliti dengan lebih dekat cabaran dan kekangan yang menyelubungi komponen terpenting pemantauan pilihan raya di Malaysia iaitu pemerhati pilihan raya domestik. PRU-14 telah mencipta sejarah tersendiri dalam konteks pemerhati pilihan raya apabila beberapa pasukan daripada institusi pengajian tinggi Malaysia diberi kebenaran untuk turut serta dalam PRU bersejarah tersebut. Penyertaan ini telah menambah komponen pasukan pemerhati yang selama ini hanya terdiri dalam kalangan NGO. Berbanding NGO, makalah ini berpendirian bahawa pasukan pemerhati daripada kumpulan akademik berpotensi memberi input yang lebih konstruktif dan seimbang terhadap proses pemerhatian dan penghasilan laporan pilihan raya berikutan sifatnya yang dekat dengan proses penyelidikan pilihan raya dan kedudukannya yang lebih neutral secara relatif. Memandangkan bidang pemerhatian pilihan raya di Malaysia masih baharu, amatur dan mempunyai banyak kelemahan, penglibatan ahli akademik dapat 
meminimumkan kelemahan-kelemahan ini dengan syarat ia dianggotai mereka yang berkelayakan dan berkredibiliti. Pasukan pemerhati akademik juga harus diberi sokongan yang kuat khususnya oleh institusi pengajian yang terlibat sama ada daripada segi logistik, kewangan dan penglibatan pihak berkepentingan seperti mahasiswa. Menjelang PRU-15, usaha ke arah pengwujudan pasukan pemerhati akademik yang lebih besar dan inklusif merupakan idea yang berpotensi untuk direalisasikan.

Makalah ini walau bagaimanapun tidak memberi maksud bahawa penglibatan kumpulan pemerhati pilihan raya daripada pelbagai NGO yang lain tidak penting dan harus dipandang dengan skeptikal. Pemantauan pilihan raya seperti yang dihujahkan oleh seorang pakar pilihan raya tempatan, Ong Boon Keong ialah usaha menggalakkan warganegara "take ownership of elections" (dipetik daripada Loh 2010). Justeru, kepelbagaian penyertaan daripada pelbagai pihak dan latar berkepentingan khususnya selepas PRU-14 merupakan sesuatu yang harus dirai, disokong dan terus digalakkan. Namun begitu, seperti yang dirumuskan dengan baik oleh bekas Pengerusi NIEI, K. Shan (2019):

Lagi banyak orang buat pemerhatian lagi bagus. Akademik pun buat, media pun buat, rakyat pun buat. Katakan petani nak buat, buatlah. Everybody yang ada interest dengan (pilihan raya), boleh buat. Tapi dia kena guided by thinking untuk membantu dan menambah baik proses. Kalau dia nak gunakan ia untuk political agenda, then (bidang pemerhatian pilihan raya akan bermasalah). Yang inilah yang banyak berlaku di Malaysia sehingga kini.

\section{PENGHARGAAN}

Kami merakamkan penghargaan kepada kepada UKM yang membiayai kajian ini menerusi geran GUP 2018-161; kepada SPR yang merupakan rakan kolaborasi projek; kepada kesemua informan yang ditemu bual serta barisan asal pasukan pemerhati pilihan raya UKM dari Pusat Dasar dan Governans Global, UKM.

\section{RUJUKAN}

\section{Sumber Primer}

Abdul Rashid Abdul Rahman. 2019. Chairman of Electoral Reform Committee (ERC) and former Chairman of Election Commission (2000-2008). Interview. 14 January. Kuala Lumpur.

Alvia, E. 2019. Secretary General of NAMFREL. Interview. 12 April. Manila. 
Amir Ridzuan Jamaluddin. 2019. Senior Executive of Institute for Democracy and Economic Affairs (IDEAS). Interview. 17 January. Kuala Lumpur.

Arphan Ahmad. 2018. Secretary General of MAFREL. Interview. 20 December. Kota Damansara.

Azuwan Marjan. 2018. Vice President of Sabah Youth Council (MBS). Interview. 18 December 2018. Kota Kinabalu.

Chandanie Watawala. 2019. Executive Director of Asian Network for Free Elections (ANFREL). Interview. 11 February. Bangkok.

Chandra Muzaffar. 2019. Former member of Election Watch 1990. Interview. 19 January. Petaling Jaya.

Francis Paul Siah. 2019. Founder of Movement for Change Sarawak (MoCS). Interview. 15 January. Petaling Jaya.

Hadar Nafis Gumay. 2019. Founder of Network for Democracy and Electoral Integrity (NETGRIT) and former Acting Chairman of KPU 2016. Interview. 27 March. Jakarta.

Jais Abdul Karim. 2019. President of Malaysian Corruption Watch (MCW). Interview. 6 March. Kajang.

K. Shan 2019. Former Chairman of National Institute for Electoral Integrity (NIEI). Interview. 30 December. Bangsar.

Mohamed Zain Abang Ismail. 2018. Secretary General of Sarawak Malay National Association (PKMS). Interview. 16 December. Kuching.

Mohd Hashim Abdullah 2019. Former Chairman of Election Commission 2016-2018. Interview. 6 January. Putrajaya.

Mohd Shukur Khalid. 2019. Strategic Secretary of Delimitation of Election Commission. Interview. 6 January. Putrajaya.

Ona Caritos. 2019. Executive Director of Legal Network for Truthful Elections (LENTE). Interview. 12 April. Manila.

Paul Low. 2019. Former Minister of Prime Minister Department. Interview. 11 January. Damansara.

Prajak Kongkirati. 2019. Head of Political Science Programme, University of Thammasat. Interview. 12 February. Bangkok.

\section{Sumber Sekunder}

Asunka, J., S. Brierley, M. Golden, E. Kramon and G. Ofosu. 2017. Electoral fraud or violence: The effect of observers on party manipulation strategies. British Journal of Political Science 1(1): 1-23. https://doi.org/10.1017/S0007123416000491

Beaulieu, E. and S.D. Hyde, 2009. In the shadow of democracy promotion: Strategic manipulation, international observers and election boycotts. Comparative Political Studies 42(3): 392-415. https://doi.org/10.1177/0010414008325571

Benstead, L., K. Kao and E. Lust. 2015. Why does it matter what observers say? The impact of international monitoring on the electoral legitimacy. Conference paper of service provision in a changing Arab world, "the second annual conference of the governance and local development (GLD) center”, Yale University. 9 April. 
Bjornlund, E.C. 2004. Beyond free and fair: Monitoring elections and building democracy. Baltimore: The John Hopkins University Press.

Bush, S.S. and L. Prather. 2017. The promise and limits of election observers in building election credibility. The Journal of Politics 79(3): 921-935. https://doi .org/10.1086/691055

2018. Who's there? Election observer identity and the local credibility of elections. International Organization 72(1): 659-692. https://doi.org/10.1017/ S0020818318000140

Buzin, A., K. Brondum and G. Robertson. 2016. Election observer effects: A field experiment in the Russian Duma election of 2011. Electoral Studies 44(1): 184191. https://doi.org/10.1016/j.electstud.2016.06.018

Callahan, W. 2000. Pollwatching, elections and civil society in Southeast Asia. Singapore: Ashgate.

Carothers, T. 1997. The observers observed. Journal of Democracy 8(3): 17-31. https://doi.org/10.1353/jod.1997.0037

Case, W. 1993. Semi-democracy in Malaysia: Withstanding the pressures for regime change. Pacific Affairs 66(2): 183-205. https://doi.org/10.2307/2759366

2004. New uncertainties for an old pseudo-democracy: The case of Malaysia. Comparative Politics 37(1): 83-104. https://doi.org/10.2307/4150125

Cecire, M. 2013. Georgia's 2012 elections and lessons for democracy promotion. Orbis 57(2): 232-250. https://doi.org/10.1016/j.orbis.2013.02.003

Chigudu, D. 2015. Foreign election observers in Africa: Towards an obligationsbased approach. Mediterranean Journal of Social Sciences 6(1 S1): 272-278. https://doi.org/10.5901/mjss.2015.v6n1s1p272

Commonwealth. 1990. Commonwealth Election Report. General Election in Malaysia. London: Commonwealth Publication.

Cooley, A. 2015. Countering democratic norms. Journal of Democracy 26(3): 49-63. https://doi.org/10.1353/jod.2015.0049

Debre, M.J. and L. Morgenbesser. 2017. Out of the shadows: Autocratic regimes, election observation and legitimation. Contemporary Politics 23(3): 328-347. https://doi.org/10.1080/13569775.2017.1304318

Funston, J. 2000. Malaysia's tenth elections: Status quo, reformasi or Islamization. Contemporary Southeast Asia 22(1): 23-59. https://doi.org/10.1355/CS22-1B

Goldman, R.M. and H. Pascual. 1988. NAMFREL: Spotlight for democracy. World Affairs 150(4): 223-231.

Gromping, M. 2017. Domestic monitors. In Election watchdogs, eds. P. Norris and N. Alesandro, 167-190. New York: Oxford University Press. https://doi.org/10.1093/ acprof:oso/9780190677800.003.0009

Herron, E.S. 2010. The effect of passive observation methods on Azerbaijan's 2008 presidential election and 2009 referendum. Electoral Studies 29(1): 417-424. https://doi.org/10.1016/j.electstud.2010.03.013

Hyde, S.D. 2011. The pseudo-democrat's dilemma: Why election observers become an international norm. Ithaca: Cornell University Press. https://doi.org/10.7591/ cornell/9780801449666.001.0001 
Ichino, N. and M. Schundeln. 2012. Deterring or displacing electoral irregularities? Spillover effects in observers in a randomized field experiment in Ghana. Journal of Politics 74(1): 292-307. https://doi.org/10.1017/S0022381611001368

International Institute for Democracy and Electoral Assistance (International IDEA). 1997. Code of conduct: Ethical and professional observation of elections. Stockholm: International IDEA Publication.

Irwan Shafrizan Ismail and H.K. Kannan. 2018. 6 pertubuhan jadi pemerhati PRK DUN Sungai Kandis. Berita Harian Online. 19 July. https://www.bharian.com.my/ berita/politik/2018/07/451219/6-pertubuhan-jadi-pemerhati-prk-dun-sungaikandis (accessed 4 February 2019).

Khoo, Y.H. 2014. Human rights advocacy in Malaysia: The case of the Suara Rakyat Malaysia (SUARAM). Malaysian Journal of International Relations 2: 130-150. https://doi.org/10.22452/mjir.vol2no1.7

2016. Malaysia's 13th general elections and the rise of electoral reform movement. Asian Politics \& Policy 8(3): 418-435. https://doi.org/10.1111/aspp.12273

Kuzel, R. 2004. Monitoring the media during an election campaign memo 98, Slovakia. In Promoting and defending democracy: The work of domestic election observer groups around the world, eds. O'Grady, P., R. Lopez-Pintor and M. Stevens, 68-75. London: NEEDS.

Levitsky, S. and L. A. Way. 2010. Competitive authoritarianism: Hybrid regimes after the cold war. New York: Cambridge University Press. https://doi.org/10.1017/ CBO9780511781353

Lidauer, M. and E. Gil. 2015. Domestic election observation: Key concepts and international standards. Briefing paper 52. Berlin: Democracy Reporting International.

Lim, H.H. 2002. Electoral politics in Malaysia: 'Managing' elections in a plural society. In Electoral politics in Southeast and East Asia, eds. A. Croissant, G.G. Bruns and M. John, 101-148. Singapore: Friedrich Ebert Stiftung.

Loh, D. 2010. Watching our elections. The Nut Graph. 26 May. http://www.thenutgraph .com/watching-our-elections/ (accessed 16 February 2019).

Loh, F.K.W. 2005. Siri Syarahan Umum Perlantikan Profesor USM: Politik baru di Malaysia? Pulau Pinang: Penerbit Universiti Sains Malaysia.

Lopez-Pintor, R. 2004a. Introducing the work of domestic election observers. In Promoting and defending democracy: The work of domestic election observer groups around the world, eds. P. O'Grady, R. Lopez-Pintor and M. Stevens, 3-9. London: NEEDS.

2004b. Concluding remarks and lessons learned. In Promoting and defending democracy: The Work of domestic election observer groups around the world, eds. P. O'Grady, R. Lopez-Pintor and M. Stevens, 113-114. London: NEEDS.

Lynge-Mangueira, H. 2012. Why 'professionalizing' international election observation might not be enough to ensure effective election observation. Stockholm: International IDEA Publication.

Magbul, D. and T. Zhvania. 2004. The role of observers on election day: NAMFREL: The Philipinnes. In Promoting and defending democracy: The Work of domestic election observer groups around the world, eds. P. O'Grady, R. Lopez-Pintor and M. Stevens, 82-91. London: NEEDS. 
Malaysiakini. 2017. Selepas setahun serbuan, SOSMA, polis tutup kes BERSIH. 22 November. https://www.malaysiakini.com/news/402831 (accessed 22 November 2017).

Merloe, P. 2015. Election monitoring vs. disinformation. Journal of Democracy 26(3): 79-93. https://doi.org/10.1353/jod.2015.0053

Muhamad Takiyuddin Ismail. 2019. Bantuan demokrasi dan pendanaan asing di Malaysia: Melewati pertukaran rejim. Kuala Lumpur: Penerbit Universiti Malaya.

Muhamad Takiyuddin Ismail and Muhamad Nadzri Mohamed Noor. 2018. Revolusi senyap 9 Mei 2018. Jebat: Malaysian Journal of History, Politics \& Strategic Studies 45(2): 161-185.

Muhammad Fathi Yusof. 2014. Konsep caretaker government: Di mana peranan SPR? 1-10. (unpublished article). Universiti Teknologi Malaysia.

Muhammad Fathi Yusof, Mohd Al'Ikhsan Ghazali, Nurhidayu Rosli and Muhammad Sakirin Alias. 2015. Public perception towards the election commission in Malaysia. Asian Social Science 11(26): 347-357. https://doi.org/10.5539/ass .v11n26p347

Norris, P. 2017. Strengthening electoral integrity. New York: Cambridge University Press. https://doi.org/10.1017/9781107280656

Ong, K.M. 2005. Examining the electoral roll. In Elections and democracy in Malaysia, eds. M. Puthucheary and Norani Othman, 292-315. Bangi: Penerbit Universiti Kebangsaan Malaysia.

Ostwald, K. 2013. How to win a lost election: Malapportionment and Malaysia's 2013 general election. The Commonwealth Journal of International Affairs 102(6): 521-532. https://doi.org/10.1080/00358533.2013.857146

PEMANTAU. 2014. Clean \& Fair: An Election observation report for GE13. Petaling Jaya: EMPOWER.

Saravanamuttu, J. 2016. Power sharing in a divided nation: Mediated communalism and new politics in six decades of Malaysia's elections. Singapore: ISEAS Publishing. https://doi.org/10.1355/9789814695428

Sjoberg, F.M. 2012. Making voters count: Evidence from field experiments about the efficacy of domestic election observation. Paperwork no. 1. Harriman Institute Seminar, Columbia University, New York. https://doi.org/10.2139/ssrn.2133592

Skovoroda, R. and T. Lankina. 2017. Fabricating votes for Putin: New tests of fraud and electoral manipulations from Russia. Post-Soviet Affairs 33(2): 100-123. https://doi.org/10.1080/1060586X.2016.1207988

Suruhanjaya Pilihan Raya. 2013. Laporan Pilihan Raya Umum ke-13. 2018. Surat SPR kepada pengkaji. SPR.600-1/3/1Jld.3(19). 30 October. 2019. E-mel kepada pengkaji. 20 February.

Tadem, T.S.E. 2007. Electoral politics and the "democratic deficit". Kasarinlan: Philippine Journal of Third World Studies 19(2): 1-3.

The Malay Mail Online. 2017. Suhakam to monitor GE14 integrity. 10 December. http://www.themalaymailonline.com/malaysia/article/suhakam-to-monitor-ge14 integrity\#WCmgBCdKuuwghg6t.97 (accessed 27 January 2018). 
Tunde, S.R., Mohd Azizuddin Mohd Sanni and Ummu Atiyah Ahmad Zakuan. 2016. Election administration and democratic sustainability in Nigeria. The Social Science 11(1): 6141-6148.

Ufen, A. 2013. The 2013 Malaysia elections: Business as usual or part of a protracted transition? Journal of Current Southeast Asian Affairs 32(2): 3-17. https://doi .org/10.1177/186810341303200201

Wan Ahmad Wan Omar. 2014. Saya, SPR dan pilihan raya. Shah Alam: Kumpulan Karangkraf.

Washida, H. 2018. Distributive politics in Malaysia: Maintaining authoritarian party dominance. Oxon: Routledge. https://doi.org/10.4324/9781315206752

Weiss, M.L. 2000. The 1999 Malaysian general elections: Issues, insults, and irregularities. Asian Survey 40(3): 413-435. https://doi.org/10.2307/3021154 2016. Payoffs, parties, or policies: Money politics and electoral authoritarian resilience. Critical Asian Studies 48 (1): 77-99. https://doi.org/10.1080/146727 15.2015.1126139

Wong, C.H. 2018. Constituency delimitation and electoral authoritarianism in Malaysia. The Round Table 107(1): 67-80. https://doi.org/10.1080/00358533.2018.14240 75 